https://doi.org/10.15407/scin16.01.031

BOUBLYK, S.G., BULKIN, I.A., and MEKH, O.A. Dobrov Institute for Scientific and Technological Potential and Studies of Science History, the NAS of Ukraine, 60 , Shevchenko Blvd, Kyiv, 01032, Ukraine, +380 44486 9591, S.Boublyk@nas.gov.ua

\title{
SCIENTOMETRIC EVALUATION OF SCIENCE-CENTRIC ORIENTATION OF THE NATIONAL LEGISLATION
}

Introduction. The ability to build a science-intensive economy in Ukraine depends on the implementation of strategic approaches to the formation and implementation of a unified government science and technology policy. One of the main conditions for the implementation of effective government policy is to amend, in terms of quality and quantity, the applicable lawes and regulations with documents of scholarly research focus.

Problem Statement. AActual task is to assess the science-centric orientation of legislative acts as a quantitative criterion of "knowledge intensity" of the national legislation.

Purpose. To obtain scientometric evaluation of science-centric orientation of the national legislative acts.

Materials and Methods. The main methods of research are as follows: the scientometric (slang) method for the analysis of texts of legal acts and the statistical methods for structuring and comparative analysis of legislative acts as statistical units.

Results. A survey of the statistical base of legislative acts of the supreme government bodies in 1992-2018 has revealed inconsistency in the managerial decisions of the top government authorities. In addition, there have been established periodic, stable statistical relationships between the intensity of scientific lawmaking and the expenditure on scholarly research and RESD activities. The original scientometric approaches to assessing the science-centric orientation of the national legislation have been developed.

Conclusions. Within the period of independence, the main problems of public administration regarding science and technology sphere in Ukraine have been as follows: competition for executive powers between the Cabinet of Ministry and the Presidential Administration; the focus of the Cabinet of Ministers on the redistribution of expenditures on science; the absence of strategic (long-term) approaches to the formation and implementation of a single RED policy at the government level. It is necessary to reform the system of legislation of Ukraine for the sake of its science-centric orientation, in particular, because of the urgent need to harmonize it with the legislation of the European Union in the field of science, technology, and innovation.

Keywords: science, legislation, science-centric legislative acts, $R \mathcal{E} \mathcal{F}$ sphere, and index of science-centric orientation.

Citation : Boublyk, S.G., Bulkin, I.A., and Mekh, O.A. Scientometric Evaluation of Science-Centric Orientation of the National Legislation. Sci. innov. 2020. V. 16, no. 1. P. 31-44. https://doi.org/10.15407/ scine16.01.031 
Technologically advanced countries of the world are building their legal and regulatory framework for R\&D based on the principle of efficient end product. Therefore, one of the main conditions for a science-intensive economy saturated with fundamental scientific discoveries that dominate in the product and process innovation (production) is the quantitative and qualitative regulatory and legal framework containing science-centric documents, or, in the first approximation, "scienceor knowledge-content documents". However, the present-day Ukraine has been experiencing a significant problem in this sphere.

Legislative support of the national R\&D sphere (RDS) is governed by a number of legislative acts, in particular, the Laws of Ukraine on Scientific and R\&D Activities (framework Law), on the Priority Areas of Science and Technology, on Innovative Activities, on R\&D Information, on scientific and R\&D Evaluation, on the Special Conditions for Innovation Activity of Technological Parks, on Scientific Parks, and on the Priority Directions of Innovation Activity in Ukraine [1]. At the same time, insights into these legislative acts show that there are certain anomalies, both in the dynamics of their development, time, and content. In other words, to answer the question why the Laws of Ukraine, as well as all related acts (decrees of the President of Ukraine, resolutions of the Verkhovna Rada of Ukraine, the Cabinet of Ministers of Ukraine, and other bylaws) governing the RDS do not "work" properly centers around the thematic content, the relevance to the stated purpose, and the synchronicity of legislative acts interrelated in terms of their thematic focus.

In particular, we are talking about poor terminological content of the texts of both the Laws and related bylaws (in particular, in the RDS field), incorrect use of terms, or asynchronous actions. As a result, all these factors certainly impair the level of science-content acts and, consequently, the knowledge content of the national RDS legislation. For example, if a specific act that regulates a particular area of activity of the real sector of the economy does not contain any direct reference to science, technology or innovation, or such references are minimized, it greatly reduces the effectiveness of RDS, and therefore minimizes the possibility of developing this field of activity in a knowledge-intensive way.

The issue of science- or knowledge-content national legislation has been repeatedly discussed at the political and expert levels [2-5]. Considering the problem of legislative support of science in Ukraine, Ukrainian researchers focus their attention mainly on improving the content of the framework law on science and related acts regulating scientific, $R \& D$ and innovative activity. Accordingly, the mechanisms developed for improving the legislation and its implementation concern the development of recommendations for legislatures and the executive bodies to improve the content of the relevant legislation [6-8].

Many researchers have contributed to addressing the problems related to the content of the texts of applicable legislation [9-12]. In particular, they have identified the general problem of interpreting science, $R \& D$, and innovation in the regulatory framework of Ukraine as an indirect indicator of the knowledge intensity level and assessed the science centricity of the acts adopted by top public bodies in the context of the formation and implementation of national R\&D policy $[11,13]$.

The terminological criterion to assess the knowledge centricity of legislative acts is the keywords from the thematic area of the text of the framework legislative act on RDS [14-17], whereas the criterion of science-centric orientation of any act is the presence in the text of the word "science" together with the first-order predicates. As evidenced by the results of the selection of slang thematic words for the definition of sciencecentered legislative acts using the scientometric (slang) method, the word "science", together with the first-order predicates, also belongs to the keywords of the text of the framework law [13-15]. Therefore, from the point of view of terminological criteria, the scientific focus of legislative 
acts can be considered as knowledge centricity, in the first approximation. Therefore, determining the scientific focus of legislative acts is an urgent scientific task for the purpose of primary assessment of the knowledge centricity of the national regulatory framework.

The purpose of this research is to make a scientometric evaluation of the scientific focus of the national legislative acts.

Scientometric evaluation of texts of legislation consists of the two stages: to determine the number of acts which texts contain the word "science" together with first-order predicates and to estimate their share in the total statistical collections of such acts, by their types (laws of Ukraine, decrees of the President of Ukraine, resolutions of the Verkhovna Rada of Ukraine and the Cabinet of Ministers of Ukraine). The methods of search by keywords in the statistical database of legislative acts, as well as statistical methods for structural and comparative analysis have been used to fulfill the research tasks.

To make scientometric thematic research of Ukrainian legislation, the terminological category "legislation" is used in its broad context, namely, as "a system of laws and other regulations adopted by the top authorities of Ukraine: the Verkhovna Rada (laws and resolutions), the President (decrees) and the Cabinet of Ministers (resolutions)" [18]. According to this definition, the statutory body of Ukrainian legislative acts for the period 1992-2018 consists of laws of Ukraine (LU), resolutions of the Verkhovna Rada of Ukraine (RVRU), decrees of the President of Ukraine (presidential decrees, PD), and resolutions and decrees of the Cabinet of Ministers of Ukraine (RCMU). From this body of documents, the acts related to remuneration policy [19] are excluded as having no sectoral focus. In addition, we adjusted the number of legislative acts for 2000 (one law did not enter into force), and for 2001, 2004, 2005, 2007, 2010, 2011, 2013, and 2017, when the amendments to some laws (the Customs Tariff of Ukraine, the Law on the National Program for the Harmonization of Ukraine's and the EU Legis- lation, and the Economic Code of Ukraine) were recorded in the database as separate documents.

For information search in the database "Legislation of Ukraine", we used the root part of "scien-" [20]. It should be noted that similar approach is also used when defining a TF-IDF statistical factor, when a keyword for informational search is reduced to its main part through the stemming algorithm (word reduction to the main part by removal ending or suffix).

Thus, 75363 documents have been selected for the relevant statistical set of legislative acts of top public authorities. Out of them, 10025 are of scientific focus (Table 1).

In previous studies, the authors have substantiated scientific assumptions about the expediency of using such a concept as "science-centered" legislation [11,13]. The basis for such a statement (scientific hypothesis) is the logical-semantic relationship between the shares of the documents that have direct or indirect influence on regulating the conditions of $R \& D$ activity in the framework legislation.

To confirm or to refute this scientific hypothesis, there has been conducted a study of the intensity of lawmaking by types of legislative acts (columns 2, 4, 6, and 8, Table 1) with the dynamics of expenditures on science and R\&D (Fig. 1). We will try to find out to what extent the activation of lawmaking influences investments in science and $R \& D$ and in which types of legislative acts there is a significant correlation between these two factors. This approach is less indirect than comparing the dynamics of derivatives, the share of science-focus acts in the aggregate dataset and the share of scientific expenditure in gross domestic product (GDP) [13]. It eliminates the overall intensity of lawmaking (which may not relate to science at all) and changes in GDP itself (which may be caused by factors not related to scientific development). So, this approach does not contain additional derivative variables, since mediation always complicates interpretation.

The intensity of lawmaking for all types of legislative acts is approximated by a curve in the form 
Table 1. The Number of Legislative Acts of Ukraine in 1992-2018

\begin{tabular}{|c|c|c|c|c|c|c|c|c|}
\hline \multirow{3}{*}{$\begin{array}{c}\text { Year } \\
1\end{array}$} & \multicolumn{8}{|c|}{ Legislative Acts of Top Public Authorities, Documents } \\
\hline & \multicolumn{2}{|c|}{ Laws of Ukraine } & \multicolumn{2}{|c|}{ Resolutions of VRU } & \multicolumn{2}{|c|}{$\begin{array}{c}\text { Decrees of the President } \\
\text { of Ukraine }\end{array}$} & \multicolumn{2}{|c|}{ Resolutions of CMU } \\
\hline & 2 & 3 & 4 & 5 & 6 & 7 & 8 & 9 \\
\hline & "scien-" & total & "scien-" & total & "scien-" & total & "scien-" & total \\
\hline 1992 & 33 & 122 & 28 & 300 & 34 & 424 & 174 & 744 \\
\hline 1993 & 31 & 132 & 25 & 339 & 28 & 414 & 230 & 1123 \\
\hline 1994 & 17 & 129 & 35 & 320 & 47 & 620 & 163 & 854 \\
\hline 1995 & 25 & 153 & 23 & 326 & 74 & 879 & 192 & 1057 \\
\hline 1996 & 18 & 203 & 33 & 412 & 81 & 912 & 276 & 1535 \\
\hline 1997 & 30 & 196 & 30 & 530 & 85 & 812 & 244 & 1429 \\
\hline 1998 & 28 & 166 & 21 & 381 & 77 & 846 & 288 & 1877 \\
\hline 1999 & 41 & 296 & 37 & 597 & 119 & 1003 & 294 & 1832 \\
\hline 2000 & 52 & 295 & 42 & 467 & 128 & 991 & 283 & 1590 \\
\hline 2001 & 55 & 236 & 32 & 377 & 106 & 918 & 261 & 1371 \\
\hline 2002 & 35 & 232 & 41 & 348 & 86 & 796 & 264 & 1417 \\
\hline 2003 & 43 & 317 & 58 & 592 & 78 & 1082 & 223 & 1407 \\
\hline 2004 & 48 & 296 & 43 & 541 & 91 & 966 & 233 & 1283 \\
\hline 2005 & 43 & 284 & 51 & 629 & 90 & 1539 & 152 & 1264 \\
\hline 2006 & 44 & 245 & 42 & 498 & 100 & 820 & 255 & 1835 \\
\hline 2007 & 15 & 103 & 37 & 649 & 91 & 770 & 263 & 1390 \\
\hline 2008 & 22 & 157 & 11 & 554 & 136 & 830 & 196 & 1140 \\
\hline 2009 & 29 & 246 & 42 & 675 & 136 & 724 & 217 & 1403 \\
\hline 2010 & 44 & 263 & 38 & 802 & 105 & 1061 & 216 & 1248 \\
\hline 2011 & 45 & 381 & 51 & 957 & 145 & 1009 & 295 & 1399 \\
\hline 2012 & 64 & 357 & 49 & 826 & 68 & 569 & 211 & 1202 \\
\hline 2013 & 10 & 151 & 45 & 541 & 80 & 526 & 173 & 962 \\
\hline 2014 & 34 & 227 & 38 & 821 & 42 & 820 & 122 & 702 \\
\hline 2015 & 48 & 350 & 38 & 474 & 75 & 503 & 168 & 1153 \\
\hline 2016 & 27 & 207 & 50 & 650 & 50 & 379 & 152 & 1008 \\
\hline 2017 & 35 & 183 & 17 & 267 & 33 & 276 & 140 & 1044 \\
\hline 2018 & 23 & 158 & 26 & 236 & 35 & 277 & 198 & 1134 \\
\hline Total & 939 & 6085 & 983 & 14109 & 2220 & 20766 & 5883 & 34403 \\
\hline
\end{tabular}

Source: author's method.

of the letter "M" with local peaks in 2000 and 2011 with a significant increase in the first nine years of independence (from 272 to 505 documents), an intermediate wave with a local minimum in 2005 , and a drastic decrease in the last six years (from 538 to 224 documents). The difference between the total number of legislative acts for individual years on the whole dataset was 2.4 times.
The dynamics of $\mathrm{R} \& \mathrm{D}$ expenditure is asymmetric and consists of three stages: an extremely sharp drop in 1992-1999 (2.6 times against the level of the initial year), a notable increase in the next five years (1.55 times with a local peak in 2004), and an expanded reduction over a further period despite the attempts to stabilize the situation in 2012-2013. In 2005-2017, the aggregate 


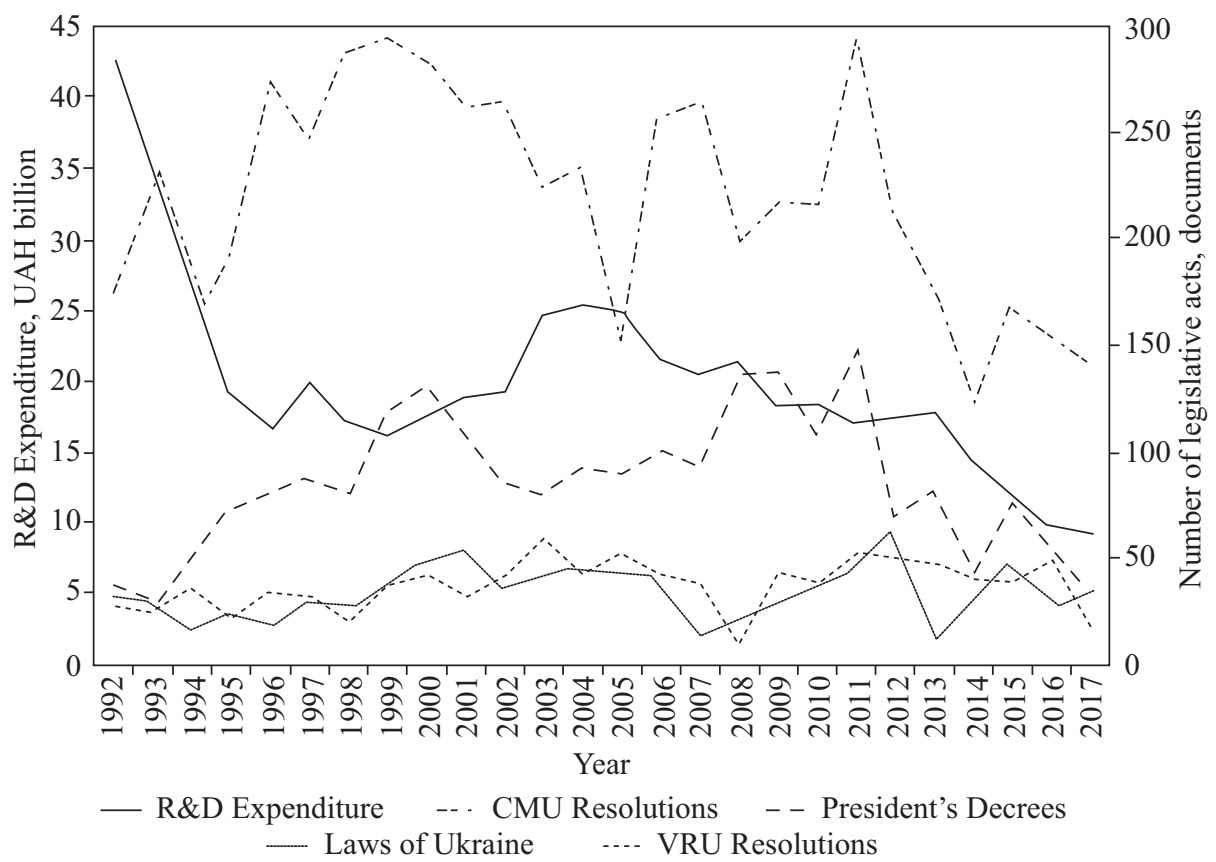

Fig. 1. Dynamics of Intensity of Approval of Science-centric orientation Legislative Acts by Types (Documents) and Expenditure on R\&D in fixed prices of 2015 (UAH billion)

decrease (2.71 ticxceeded the drop of the 1990s. As a result of the persistent negative trend, against the background of different annual trends in GDP growth, in those years there was an even greater fall (2.74 times) in the knowledge intensity of GDP, i.e. the priority of science over other goals of socio-economic development. For comparison, in 1992-1999, the knowledge intensity of GDP decreased only 1.29 times. This means, unlike the last stage, that time, decreasing support of science was caused by justifiable reason, the negative dynamics of GDP.

Overall, expenditure on $R \& D$ in Ukraine has decreased 4.56 times over 26 years, which, from a formal point of view, far exceeds the variance in the number of legislative acts. However, given that the number of legislative acts reduced, in 2011-2017, it is also appropriate to compare it with the drop in the expenditure during this period. In this case, it is smaller and is 1.85 times.

It is easy to see that the adoption of documents and the R\&D expenditure have opposite trends: the first wave of lawmaking growth (1995-2000) corresponded to a drop in the expenditure while its slump in 2001-2005 was accompanied by an increasing the expenditure to its maximum in the 21st century (2003-2005). Over the next five years, the local intensification of lawmaking took place against a backdrop of progressively falling R\&D expenditure, and only after 2011, dynamics of both indicators started to develop similarly. However, there is no reason for optimism: in both cases, a negative trend has emerged, which can be explained by the fact that less attention to the R\&D lawmaking is naturally accompanied by a reduction in the resource base. It should be noted that the burst of lawmaking activity in the late 1990s in fact aimed at a financial "response" in the future (the next five years). Here, we can conclude that there is a time lag between the regulatory act and the change in the situation in the R\&D system, and sometimes this lag can last several years. Similarly, after the second peak of lawmaking (in 2011), the expenditure over the two years was slightly increasing. However, later, as science was losing its importance with respect to other socio-economic goals, the regulatory potential of the adopted legislative acts needed to 
be strengthened, and the legislative activity of 2014-2017 was insufficient. In 2017, a historical minimum of the total number of legislative acts was recorded, and the local burst of lawmaking in 2015 did not have any significant favorable effect, because it was discrete and not powerful enough (so, we can only speak about a certain slowdown in $R \& D$ expenditure dropping pace). It should be emphasized once again that at the beginning of the century, the increase in $\mathrm{R} \& \mathrm{D}$ expenditure was preceded by, at least, five-year boom of lawmaking with a focus on science. This means, the present-day Ukraine feels a sharp lack of systematic approach to the formation of R\&D policy, first of all, in terms of the legal and regulatory support.

We have calculated the correlation between the number of legal documents by types and investments in science (Tables 2,3 ). To choose time intervals for the procedure, we select the follow- ing benchmarks: 1992 as the start of independent operation of the national scientific system; 1995 as the start of R\&D expenditure slowdown; 2001 as the initial year of the current century; 2008 as baseline for the last decade of observations; 2011 as the start of the current calendar decade. We do not deny the possibility of their expansion, in particular, by adding the data of 2004 after which a long-term reduction in $\mathrm{R} \& \mathrm{D}$ expenditure began, and of 2013 since which the slowdown pace accelerated sharply. These two periods are planned to be included into further studies. In addition to the aggregate $R \& D$ expenditure, we consider separately the expenditure from domestic sources (i.e. excluding foreign funds) and that from the national budget.

In the case of no lag (funding reacts in the same year that the legislative acts are adopted, Table 2), the correlation between the parametric series is weak, and throughout the independence era, va-

Table 2. Correlation between the Intensity of Lawmaking (the Number of Science-Focused Legislative Acts) and $R \& D$ Funding (no lag between the year of adoption and receipt of funds)

\begin{tabular}{|c|c|c|c|c|c|}
\hline Period. years & The total number of documents & RCMU & $\mathrm{PD}$ & LU & RVRU \\
\hline \multicolumn{6}{|c|}{ Total funding of science } \\
\hline $1992-2017$ & -0.089 & 0.021 & -0.204 & -0.061 & -0.081 \\
\hline $1995-2017$ & 0.401 & 0.307 & 0.415 & 0.058 & 0.231 \\
\hline $2001-2017$ & 0.539 & 0.476 & 0.488 & 0.066 & 0.264 \\
\hline $2008-2017$ & 0.611 & 0.579 & 0.759 & -0.116 & -0.037 \\
\hline $2011-2017$ & 0.611 & 0.586 & 0.610 & 0.116 & 0.586 \\
\hline \multicolumn{6}{|c|}{ Funding from domestic sources } \\
\hline $1992-2017$ & -0.173 & -0.033 & -0.278 & -0.128 & -0.157 \\
\hline $1995-2017$ & 0.345 & 0.279 & 0.389 & -0.025 & 0.135 \\
\hline $2001-2017$ & 0.503 & 0.456 & 0.485 & 0.008 & 0.181 \\
\hline $2008-2017$ & 0.524 & 0.484 & 0.711 & -0.138 & -0.122 \\
\hline $2011-2017$ & 0.541 & 0.502 & 0.527 & 0.148 & 0.579 \\
\hline \multicolumn{6}{|c|}{ Funding from the national budget } \\
\hline $1992-2017$ & -0.239 & -0.114 & -0.267 & -0.203 & -0.202 \\
\hline $1995-2017$ & 0.211 & 0.112 & 0.437 & -0.188 & 0.046 \\
\hline $2001-2017$ & 0.463 & 0.407 & 0.617 & -0.187 & -0.009 \\
\hline $2008-2017$ & 0.542 & 0.519 & 0.722 & -0.146 & -0.148 \\
\hline $2011-2017$ & 0.560 & 0.548 & 0.530 & 0.138 & 0.532 \\
\hline
\end{tabular}

Source: author's method. 
lues with a negative sign prevail. As the time interval decreases, the correlation tends to increase, which formally testifies to increasing similarity between trends in the formulation and the implementation of $R \& D$ policy. However, substantively, this is explained by aggravating the third (negative) stage of $R \& D$ expenditure dynamics, in relation to which changes in the intensity of lawmaking are analyzed. So, the important factor is not only the similarity in changes, but also the qualitative direction of the processes. More or less significant values are observed with respect to the dynamics of presidential decrees and aggregate expenditure in 2008-2017 (0.759 while the critical level is $0.708, \mathrm{P}>0.999$ ). Little bit smaller, but still valid are the values in the aspects of domestic and budget funding ( 0.711 and 0.722 , respectively). This means, the content of the presidential decrees was not limited to issues of purely government support of science and had a broad focus, and the dynamics of changes in the intensity of lawmaking correlated with the negative trend in funding, i.e. worsened. As the significance increases to $\mathrm{p}=0.05$ (0.468 in Table), the correlation of the dynamics of RCMU with R\&D funding throughout the current century is also important (0.476). In fact, it is this type of legislative acts that has determined the nature of the dynamics across the entire set of documents. In 2011-2017, the RVRU coefficient increased sharply: from a negative value to 0.586 , at a critical level of $0.576(\mathrm{P}>0.95)$. The reasons for this increase are the exclusion from the calculations of data for 2008-2010, when the intensity of lawmaking increased almost fivefold as compared with a low level in 2008, and a local peak in activity in 2016, which, however, was neutralized by the next year fall. It is interesting that the weakest correlation with the dynamics of funding in all selected aspects was reported for the number

Table 3. Correlation between the Intensity of Lawmaking (the Number of Science-Focused Legislative Acts) and $R \& D$ Funding (a year lag between the year of adoption and receipt of funds)

\begin{tabular}{|c|c|c|c|c|c|}
\hline Period. years & The total number of documents & $\mathrm{RCMU}$ & $\mathrm{PD}$ & $\mathrm{LU}$ & RVRU \\
\hline \multicolumn{6}{|c|}{ Total funding of science } \\
\hline $1992-2017$ & 0.117 & 0.242 & -0.106 & 0.067 & -0.055 \\
\hline $1995-2017$ & 0.504 & 0.480 & 0.313 & 0.142 & 0.159 \\
\hline $2001-2017$ & 0.579 & 0.680 & 0.323 & 0.143 & 0.113 \\
\hline $2008-2017$ & 0.697 & 0.699 & 0.734 & 0.096 & -0.223 \\
\hline $2011-2017$ & 0.707 & 0.733 & 0.575 & 0.367 & 0.505 \\
\hline \multicolumn{6}{|c|}{ Funding from domestic sources } \\
\hline $1992-2017$ & -0.006 & 0.159 & -0.230 & -0.003 & -0.106 \\
\hline 1995-2017 & 0.462 & 0.453 & 0.273 & 0.089 & 0.168 \\
\hline $2001-2017$ & 0.557 & 0.599 & 0.295 & 0.098 & 0.137 \\
\hline $2008-2017$ & 0.691 & 0.702 & 0.709 & 0.101 & -0.207 \\
\hline $2011-2017$ & 0.696 & 0.722 & 0.583 & 0.337 & 0.680 \\
\hline \multicolumn{6}{|c|}{ Funding from the national budget } \\
\hline $1992-2017$ & -0.064 & 0.048 & -0.173 & -0.064 & -0.096 \\
\hline 1995-2017 & 0.351 & 0.272 & 0.366 & -0.022 & 0.186 \\
\hline $2001-2017$ & 0.584 & 0.600 & 0.469 & -0.050 & 0.046 \\
\hline $2008-2017$ & 0.745 & 0.755 & 0.761 & 0.107 & -0.200 \\
\hline $2011-2017$ & 0.773 & 0.800 & 0.637 & 0.374 & 0.773 \\
\hline
\end{tabular}

Source: author's method. 
of the laws of Ukraine. In this category, the largest absolute value $(-0.203)$ was observed when considering the correlation of legislative acts with budget funding in the broadest time period, but it is less than all tabular values.

A year lag after the adoption of legislative acts (Table 3) seems more logical because of a slow reaction of regulatory bodies to the changes in the legislative framework and quite a long time for the planning and budgeting procedures. Such consideration enables obtaining higher correlation coefficients.

The highest correlation coefficient $(0.800)$ is reported for the case of budget expenditure and RCMU over the past seven years. It is significant at $\mathrm{P}>0.99$. Starting with 2008 (as the initial interval), the budgetary expenditure has been exceeding the respective expenditure from all sources collectively. Thus, in the case of a year lag, in the last decade, the RCMU were more related to budget issues. Previously, the correlation for this type of acts and budget funding was weaker than both aggregate expenditure and expenditure from domestic sources. Proceeding from unfavorable expenditure dynamics, we note that it is the budget funding that has suffered the most as a result of declining science-related lawmaking (which is the mission of the CMU). It is interesting that this conclusion is true in the case of RVRU, as well. The relationship between the processes and the dynamics of the presidential decrees have increased (reached 0.761, in 20082017), indicating that there is a competition for managerial powers between the Cabinet of Ministers and the Presidential Administration. In the category of laws of Ukraine, no stable correlation has been observed.

Thus, as a precedent, the intensification of science-related lawmaking can contribute to growing expenditure on science in Ukraine, as it happened at the turn of the century. However, as the society perceived science and $R \& D$ as something optional, since 2014, the expenditure was progressively decreasing, and fluctuations in the lawmaking could not have corrected it. A significant positive correlation between the processes at the shortened interval of recent years indicates a crisis in the science-related lawmaking rather than improving the RDS manageability.

It is advisable to use a relative indicator in order to obtain a scientific evaluation of the science-centric orientation of the legislative acts by types and legislatures. Such indicator is sciencecentric orientation index (SCOI) that is calculated as the share of science-centric legislative acts. The SCOI can be considered as a measure of knowledge content of the legislation, in the first approximation, since the determination of the science centricity of the legislative acts is based on the primary sign, namely, the presence of the most frequent keyword "science" and the firstorder predicates in their texts.

Accordingly, we have converted the data in Table 1 (columns 2-9) into the relative sciencecentric orientation indexes (Table 4).

In 1992-2018, the dynamics of SCOI of certain types of legislation (columns $2-5$, Table 4) were stochastic, because of the natural occurrence of keyword "science" and first-order predicates in the texts of legislative acts. In its turn, the occurrence of scientific slang terms in the texts of legislative acts is conditioned both by the general linguistic principles of writing any texts and by the natural stylistic diversity of the author teams who compose the texts of legislative acts of the three top public bodies of Ukraine. On the other hand, legislative acts are one of the results of administrative decisions of the respective government bodies, and their adoption is subject to certain political intentions of officials. Another factor influencing the dynamics of SCOI is the implementation of government policy measures in the field of science, which, as the history of the independence era shows, is non-systemic and therefore accidental phenomenon in the formation of the national legislation system, in 1992-2018.

Since the selected types of legislative acts form the system of the general law, in its broad context, it is possible to conduct separate scientometric evaluations of the scientific focus of the 
legislation as a whole. However, such studies require the development of a model of interrelationships between different types of legislation, which is not the subject of this research.

The analysis of the SCOIs by types of legislative acts in 1992 and their average indicators for 1992-2018 has shown that the structure remains mainly unchanged for the LUs, RCMUs, and RVRUs, with index values decreasing (Fig. 2). At the same time, the average SCOI of the PDs increases, which requires further clarification.

The tendency to decrease the average SCOI of such legislative acts as the Laws of Ukraine, RCMUs and RVRUs (Fig. 2) is in line with the downward dynamics of R\&D funding in Ukraine (Fig. 1) and is associated with detraction of VRU and CMU attention from developing the legal framework of national science. At the same time, the upward trend in the average SCOI of the presidential decrees since 1992 is explained by the establishment and development of the presidency in Ukraine, the formation of a specific thematic structure of such legislative acts, as well as by certain political preferences of individual leaders.

In order to evaluate the contribution of individual top officials of the state and convocations of the Verkhovna Rada to the development of the regulatory framework of national science for the independence era (1992-2018), the SCOIs of certain legislative acts in the corresponding cadences have been calculated. Comparison of the obtained data for cadences of the Verkhovna Rada, the Presidents of Ukraine, and the Cabinet of Ministers of Ukraine with the average values has made it possible to evaluate their role in the historical perspective of the formation of the national science-focused legislative framework (Table 5-7).

The analysis of the data in Table 5 has shown that the science-centric orientation of the LUs is usually higher than that of the RVRUs, since science is an integral part of all spheres of the state life, and therefore shall be defined in the relevant legislative acts. Trough an exception, in 2013, the SCOI of the LUs reached the lowest level in the history of lawmaking since Ukraine's independence $(6.0 \%)$ due to the small number of primary legislative acts (Table 4 ).

The SCOIs of the LUs adopted by the Verkhovna Rada of XII (I), XIV (III), and VIII convocations and the RVRUs made by Verkhovna Rada of XII-XIV (I-III), IV, and VIII convoca-

Table 4. Science-centric orientation Indexes of Separate Types of Legislative Acts, \%

\begin{tabular}{|c|c|r|r|r|}
\hline \multirow{2}{*}{ Years } & \multicolumn{4}{|c|}{ Legislative acts } \\
\cline { 2 - 5 } & RCMU & \multicolumn{1}{|c|}{ PD } & \multicolumn{1}{c|}{ LU } & RVRU \\
\hline 1 & 2 & 3 & 4 & \multicolumn{1}{c|}{5} \\
\hline 1992 & $\mathbf{2 3 . 4}$ & 8.7 & $\mathbf{2 7 . 0}$ & $\mathbf{9 . 3}$ \\
1993 & $\mathbf{2 0 . 5}$ & 6.8 & $\mathbf{2 2 . 7}$ & $\mathbf{7 . 4}$ \\
1994 & $\mathbf{1 9 . 1}$ & 7.7 & 13.2 & $\mathbf{1 0 . 9}$ \\
1995 & $\mathbf{1 8 . 2}$ & 8.4 & $\mathbf{1 5 . 7}$ & $\mathbf{7 . 1}$ \\
1996 & $\mathbf{1 8 . 0}$ & 9.1 & 8.9 & $\mathbf{8 . 0}$ \\
1997 & $\mathbf{1 7 . 1}$ & 10.7 & 15.3 & 5.7 \\
1998 & 15.3 & 9.3 & $\mathbf{1 6 . 3}$ & 5.5 \\
1999 & 16.0 & $\mathbf{1 1 . 8}$ & 13.5 & 6.2 \\
2000 & $\mathbf{1 7 . 8}$ & $\mathbf{1 3 . 1}$ & $\mathbf{1 7 . 0}$ & $\mathbf{9 . 0}$ \\
2001 & $\mathbf{1 9 . 0}$ & $\mathbf{1 1 . 5}$ & $\mathbf{2 2 . 5}$ & $\mathbf{8 . 5}$ \\
2002 & $\mathbf{1 8 . 6}$ & $\mathbf{1 0 . 8}$ & 15.1 & $\mathbf{1 1 . 8}$ \\
2003 & 15.8 & 7.3 & 13.6 & $\mathbf{9 . 8}$ \\
2004 & $\mathbf{1 8 . 2}$ & 9.5 & 14.9 & $\mathbf{7 . 9}$ \\
2005 & 12.0 & 5.8 & 14.8 & $\mathbf{8 . 1}$ \\
2006 & 13.9 & $\mathbf{1 2 . 2}$ & $\mathbf{1 7 . 1}$ & $\mathbf{8 . 4}$ \\
2007 & $\mathbf{1 8 . 9}$ & $\mathbf{1 1 . 9}$ & 12.6 & 5.7 \\
2008 & $\mathbf{1 7 . 2}$ & $\mathbf{1 6 . 4}$ & 12.7 & 2.0 \\
2009 & 15.5 & $\mathbf{1 8 . 9}$ & 11.4 & 6.2 \\
2010 & $\mathbf{1 7 . 3}$ & 10.0 & 15.6 & 4.7 \\
2011 & $\mathbf{2 1 . 1}$ & $\mathbf{1 4 . 6}$ & 11.8 & 5.3 \\
2012 & $\mathbf{1 7 . 6}$ & $\mathbf{1 2 . 0}$ & $\mathbf{1 7 . 9}$ & 5.9 \\
2013 & $\mathbf{1 8 . 0}$ & $\mathbf{1 5 . 4}$ & 6.0 & $\mathbf{8 . 3}$ \\
2014 & $\mathbf{1 7 . 4}$ & 5.1 & 15.0 & 4.6 \\
2015 & 14.6 & $\mathbf{1 5 . 1}$ & 13.7 & $\mathbf{8 . 0}$ \\
2016 & 15.1 & $\mathbf{1 3 . 7}$ & 13.0 & 7.7 \\
2017 & 13.4 & $\mathbf{1 2 . 0}$ & $\mathbf{1 8 . 6}$ & 6.5 \\
2018 & $\mathbf{1 7 . 5}$ & $\mathbf{1 2 . 6}$ & 14.6 & $\mathbf{1 1 . 0}$ \\
Total & $\mathbf{1 7 . 1}$ & $\mathbf{1 0 . 7}$ & $\mathbf{1 5 . 4}$ & $\mathbf{7 . 0}$ \\
\hline
\end{tabular}

Source: author's method.

Note. SCOIs that exceed the average value for 1992-2018 are marked with bold type. 
tions are higher than the average. Only Verkhovna Rada of XII (I), XIV (III), and VIII (the last as of today) convocations has the SCOI exceeding the average for both the LUs and the RVRUs.

It can be assumed that such a significant difference in the SCOI of different types of acts of the Verkhovna Rada is explained by the complicated and time-consuming procedure for adopting the laws and more simplified for making the resolutions. In addition, as compared with the resolutions of the Verkhovna Rada, the laws are more sensitive to political, economic, and incidental (technical) factors. Therefore, the SCOI of the laws of Ukraine (LU SCOI) seem to be the most informative for the analysis of the formation of government R\&D policy. The LU SCOI dynamics, or comparison with the average over a certain period, enable assessing how the legislative framework of R\&D activity in the country evolves. Thus, according to Table 5 , it can be stated that the LU SCOI for almost all convocations of the Verkhovna Ra- da is lower than the average, except for XII (I) and XIV (III) convocations. In particular, this indicates that in 2002-2018, except for individual years, the $\mathrm{R} \& \mathrm{D}$ development was not among the priorities for the relevant convocations of the Verkhovna Rada, which entailed a steady decline in science funding after 2004 (Fig. 1).

During the office terms of the Presidents of Ukraine (one office term of Leonid Kravchuk and two ones of Leonid Kuchma), PD SCOI was growing, which was connected both with the formation of the institution of Presidency in Ukraine and with the corresponding attitude to the development of R\&D by the first two Presidents (Table 6). During the cadences of the last three Presidents of Ukraine, the PD SCOIs were higher than the average for the independence era and statistically identical (until 2019). These highest SCOIs were reported against the background of a rapid decrease in funding and a reduction in $R \& D$ activities in Ukraine, which requires further study of the the-

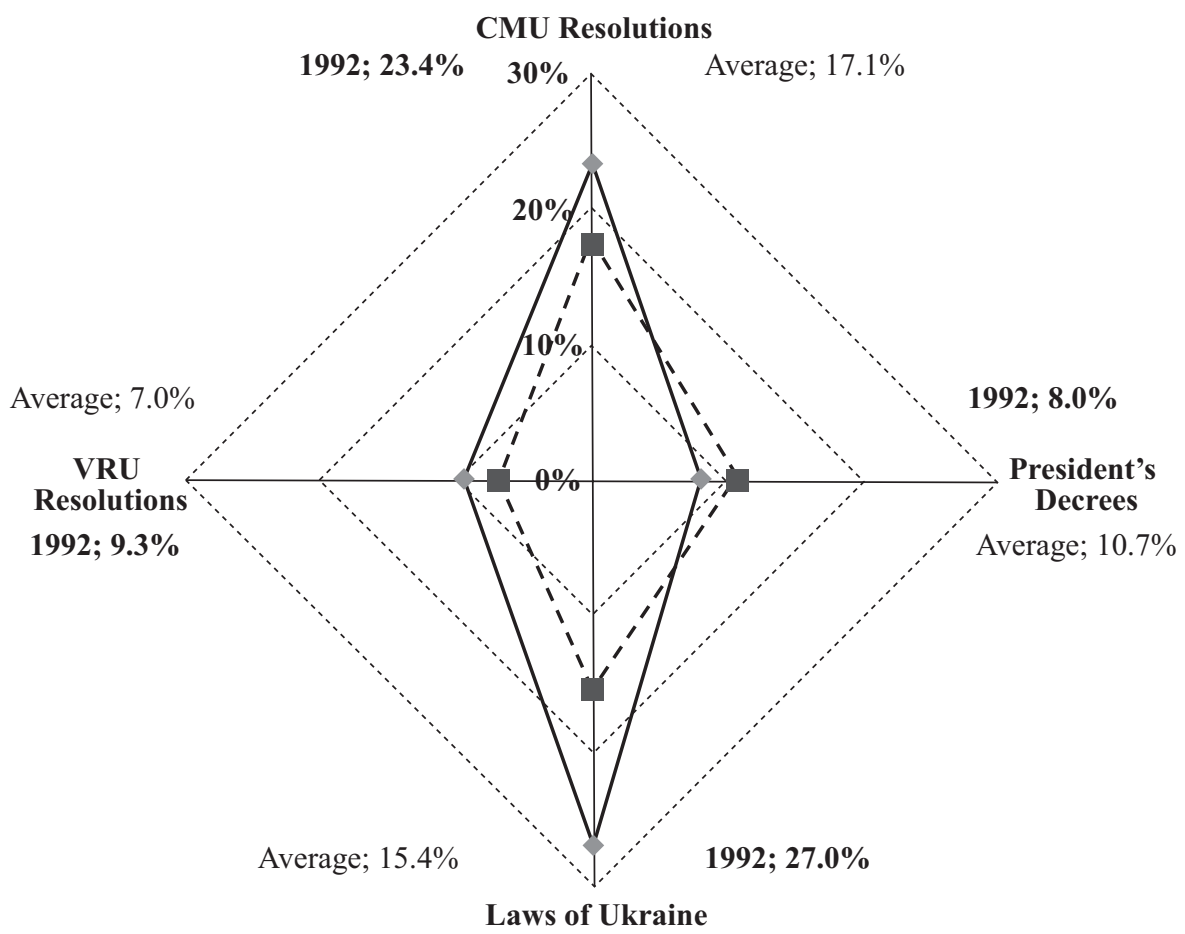

Fig. 2. Science-centric orientation Indexes by Type of Legislative Acts in 1992 and the Average for $1992-2018, \%$ 
Table 5. Science-centric orientation Indexes of the Legislative Acts (LUs. RVRUs) by VRU Convocation, \%

\begin{tabular}{|c|c|c|c|c|c|c|c|c|c|}
\hline Legislative acts & XII (I) & XIII (II) & XIV (III) & IV & V & VI & VII & VIII ** & Average * $^{*}$ \\
\hline LUs & 23.4 & 13.6 & 16.8 & 14.6 & 14.9 & 14.2 & 10.0 & 15.2 & 15.4 \\
RVRUs & 10.7 & 7.1 & 7.7 & 9.1 & 6.7 & 5.0 & 6.0 & 8.2 & 7.1 \\
\hline
\end{tabular}

Note. SCOIs that exceed the average value are marked with bold type. ${ }^{*}$ The first term of VRU I (XII) started 24.08.1991. ** Until 31.12.2018.

Source: author's method.

matic structure of administrative decisions by different political leaders of the state.

The analysis of the thematic structure of the science-related presidential decrees has enabled distinguishing the three directions, namely, the commemorative, the professional, and the social ones. The documents that aim at marking anniversaries and events of national importance and at giving tribute to outstanding figures are referred to the commemorative direction; the administrative decisions on the appointment and the dismissal from public office, as well as the assignment of higher ranks and positions are referred to the professional one; the decrees on the award of state scholarships to researchers and the status to national research institutes and higher education establishments belong to the social direction. The thematic focus of the above mentioned PDs is in line with the signs of the acts listed in paragraph 3.4 of the Order of the Ministry of Justice of Ukraine No. 34/5 of 12.04.2005 as such that do not require state registration [21]. They are not regulations since they do not contain any new legal norm. It should be concluded that the sporadic PDs in certain thematic areas, as well as PDs related to the President's remuneration policy, have no effect on the development of the national $R \& D$.

The aggregate share of the above mentioned documents in the total number of science-related PDs makes up 29.7\% for President Yushchenko, $34.0 \%$ for Yanukovych, and $45.6 \%$ for President Poroshenko (by 2019). These data confirm the thematic differences in the attitude of these Presidents of Ukraine to the legislative support of R\&D. The increase in their share in the science-related PDs, in 2005-2018, testifies to an escalating trend
Table 6. Science-centric orientation Indexes of the Legislative Acts of the Presidents of Ukraine Adopted within Their Office Terms. since the Proclamation of the Independence of Ukraine*, \% (average 10.8\%)

\begin{tabular}{|c|c|c|}
\hline $\begin{array}{c}\text { Leonid } \\
\text { Kravchuk ** }\end{array}$ & $\begin{array}{l}\text { Leonid } \\
\text { Kuchma }\end{array}$ & Leonid Kuchma*** \\
\hline 7.4 & 9.9 & 10.1 \\
\hline Viktor & Viktor & Petro Poroshenko**** \\
\hline $\begin{array}{c}\text { Yushchenko } \\
12.3\end{array}$ & $\begin{array}{c}\text { Yanukovych } \\
12.2\end{array}$ & 12.2 \\
\hline
\end{tabular}

Note. SCOIs that exceed the average value are marked with bold type. * SCOIs of presidential decrees during the office term of Acting President Oleksander Turchynov is 3.3\%. ** The office term of the President of Ukraine started 05.12.1991. *** The second office term of the President of Ukraine (1999-2005). ${ }^{* * * *}$ Until 31.12.2018.

Source: author's method.

that aims at perpetuating not only the R\&D legislative framework, but also the current problems of its development.

The science-centered focus of the RCMUs is usually the highest among other types of legislation, which is determined by their legal nature as bylaw. However, the focus of the RCMUs on the implementation of legislative acts of both the Verkhovna Rada of Ukraine and the President of Ukraine in all spheres of life of the state causes a certain lag in the adoption of respective resolutions by the Cabinet of Ministers of Ukraine: from 2-6 months as determined in the regulations to $6-12$ months, in reality. For a long time, one of the main reasons for quite a long lag between the adoption of new laws, regulations, and decrees and their implementation through the RCMUs was an often rotation of governments, as 
Table 7. Sxcience-Centric Focus Index of CMU

Resolutions Adopted During Office Terms of Prime Ministers of Ukraine. since the Proclamation of Independence of Ukraine *, \% (average 17.2\%)

\begin{tabular}{|c|c|c|c|}
\hline V. Fokin ** & L Kuchma & $\begin{array}{c}\text { Yu. Zvia- } \\
\text { hylskyi *** }\end{array}$ & V. Masol \\
$\mathbf{2 7 . 5 \%}$ & $\mathbf{2 0 . 2 \%}$ & $\mathbf{2 1 . 1 \%}$ & $15.3 \%$ \\
Ye. Marchuk & P. Lazarenko & $\begin{array}{c}\text { V. Pusto- } \\
\text { voitenko }\end{array}$ & $\begin{array}{c}\text { V. Yush- } \\
\text { chenko }\end{array}$ \\
$\mathbf{1 9 . 8 \%}$ & $16.5 \%$ & $16.1 \%$ & $\mathbf{1 8 . 7 \%}$ \\
A. Kinakh & V. Yanu- & Yu. Tymo- & Yu. Yekha- \\
& kovych & shenko & nurov \\
$\mathbf{1 8 . 3 \%}$ & $16.7 \%$ & $11.2 \%$ & $15.5 \%$ \\
V. Yanu- & Yu. Tymo- & M. Azarov & M. Azarov \\
kovych (2) & shenko (2) & & $(2)$ \\
$16.0 \%$ & $16.2 \%$ & $\mathbf{1 9 . 2 \%}$ & $\mathbf{1 7 . 4 \%}$ \\
A. Yatseniuk & A. Yatseniuk & V. Grois- & \\
& $(2)$ & man **** & \\
$\mathbf{1 7 . 5 \%}$ & $14.8 \%$ & $15.4 \%$ & \\
\hline
\end{tabular}

Note. ${ }^{*}$ oexcept for Acting Prime Minister. ** The office term of Prime Minister is counted from 24.08.1991. ${ }^{* * *}$ The office term of Acting Prime Minister is compared to office term of several Prime Ministers. V. Yanukovych (2), Yu. Tymoshenko (2), M. Azarov (2), and A. Yatseniuk (2) the second office terms as Prime Ministers. *** UNTIL 31.12.2018.

Source: author's method.

in the independence era of Ukraine (until 2019), there have recorded seventeen Prime Ministers. Only M. Azarov served as Prime Minister (two terms) throughout the office term of one President, and not a single has occupied this position for the whole convocation of the Verkhovna Rada. This fact became one of the main reasons for the "fire extinguishing" measures taken by governments, especially in the 1990s, when the adoption of the RCMU was a response to the state of affairs, and the effectiveness of such administrative decisions depended on the professionalism of members of the Cabinet of Ministers. Therefore, comparing the RCMU SCOIs related to office terms of different Prime Ministers throughout the independence era of Ukraine, is a non-trivial task, and in the current study is used as a clear example, without taking into account all the above factors.
The governments that have a higher SCOI than the average are listed in the descending order: V. Fokin, Yu. Zviahylskyi (as acting Prime Minister), L. Kuchma, Ye. Marchuk, M. Azarov (the first and the second office terms), V. Yushchenko, A. Kinakh, and A. Yatseniuk (the first office term) (Table 7). It should be noted that the governments of V. Fokin, L. Kuchma, and Yu. Zviahylskyi were the first ones in the independence era and used similar methodological approaches to the formation of thematic areas of RCMUs. The same is true for the government of Ye. Marchuk (the 5th in succession). The lowest RCMU SCOI belongs to the first Yulia Tymoshenko's government whose office term was the shortest one (less than eight months). The office term of the first cadence of A. Yatseniuk's government (nine months) was not much longer, but at that time there was a period of mass reorganizations of the existing state administration bodies and the creation of new bodies (for example, the Business Ombudsman Council), which had signs of science-related.

Summarizing the results of scientometric study of the national legislation for 1992-2018, we have concluded as follows.

1. The intensification of science-related lawmaking may contribute to an increase in expenditure on science in Ukraine. However, the further rooting in society of the attitude towards $R \& D$ as something optional may lead to a crisis of sciencerelated lawmaking. The only way out of this situation is to change the strategic approaches to the formation and implementation of the government R\&D policy and its constant monitoring at the highest level, like in the case of the financial policy.

2. The science-centric orientation of legislative acts (LUs, RVRUs, and RCMUs) shows steady downward dynamics (since 1992), which does not provide favorable regulatory and legal conditions for R\&D in Ukraine and is one of the reasons for a decline in the national RDS.

3. The analysis of the thematic structure of the science-related presidential decrees of the last three Presidents of Ukraine (Yushchenko, Yanuko- 
vych, and Poroshenko) has shown that their policy in the field of science aimed at perpetuating not only the legislative framework of $\mathrm{R} \& \mathrm{D}$, but also the current problems of its development.

4. The multi-vector trend of the development of science-related presidential decrees, laws of Ukraine, resolutions of VRU and CMU testifies to the lack of strategic approaches in the formation of the legislative framework for the development of Ukrainian science, which is the main obstacle for the formation and implementation of a wellbalanced government R\&D policy.
5. One of the main directions for reforming the system of the legislation of Ukraine in the context of its science-centric orientation is the urgent need to harmonize it with the legislation of the European Union in the field of science, technology, and innovation.

The further directions of the study include the structural (thematic) analysis of the legislative acts and the identification of main factors that influence the formation of the science-centric orientation legislative framework by top public authorities in Ukraine.

\section{REFERENCES}

1. Legislation of Ukraine in the field of scientific, scientific and technical, and innovative activity: Collection legislation. acts: as of February 12013 (Verkhovna Rada of Ukraine, Commitee on Science and Education). (2013). L.M. Grinevich (ed.); order: M.M. Shevchenko et al. Kiev: Parliamentary Publishing House [in Ukrainian].

2. State and legislative support for financing scientific and technical activities in Ukraine. hearing materials at the Verkhovna Rada of Ukraine Committee on Science and Education March 13. 2013 (Verkhovna Rada of Ukraine, Committee on Science and Education). (2014). L.M. Grinevich (ed.); order: M.M. Shevchenko et al. Kiev: Parliamentary Publishing House [in Ukrainian].

3. On the state and problems of financing education and science in Ukraine. Materials parlam. hearings in the Verkhovna Rada of Ukraine on November 16. 2016 (Verkhovna Rada of Ukraine, Committee on Science and Education). (2017). O.V. Spivakovs'kyy (ed.); order: O. M. Levchuk et al. Kiev: Parliamentary Publishing House [in Ukrainian].

4. Parliamentary hearing: «National innovation system: status and law enforcement development». Recommendations project. (2018). Ekonomist, 3(377), 19-25 [in Ukrainian].

5. Paton, B. Ye. (2015). On the activities of the National Academy of Sciences of Ukraine in 2009-2014, respectively, and the main task of the next period (report at the session of the General Meeting of NAS of Ukraine 15 April 2015). Visnyk NAN Ukraine, 5, 15-21 [in Ukrainian].

6. Pakhomova, A. O. (2011). General characteristics of the legislation used research. Visnyk of the Academy of Advocates of Ukraine, 2(21), 52-58 [in Ukrainian].

7. Popovych, O. S., Kapitsa, Yu. M. (2012). The legal field of science requires substantial improvement: before the amendments to the Law of Ukraine «On Scientific and Scientific and Technical Activities» are adopted. Science and Science of Science, 4(78), 32-39 [in Ukrainian].

8. Nahorichna, O. S., Konovalov, Yu. O. (2014). Legislative support for the process of state regulation of research activities. Public administration, improvement and development, 5. URL: http://nbuv.gov.ua/UJRN/Duur_2014_5_12 (Last accessed: 01.02.2019) [in Ukrainian].

9. Avigdor, G., Atamanova, Y., Bulkin, I., Butnik-Siversky, O., Galenko, I., Isakova, N., ..., Shkvorets, Yu. (2011). The analysis of the legislation of Ukraine in the sphere of research, developments and innovation activity and suggestions for amendments for legislation. EU Project "Enhance Innovation Strategies, Policies and Regulation in Ukraine". Kiyv: Fenix.

10. Belevtsova, S. O. (2012). Current Problems of Modern National Legal Terminology Proceedings of Kharkiv National Pedagogical University GS Pans. «Right», 2012, Kharkiv, 144-149.

11. Mekh, O. A. (2014). Research Intensity of the National Security of Ukraine: Analysis of Legal Principles. Science and science of science, 3(85), 11-22 [in Ukrainian].

12. Boublyk, S. G. (2016). Scientific Approach to Analysis of Legal Acts in Science and Technology Field. Science and science of science, 2(92), 26-39 [in Russian].

13. Boublyk, S. G. (2017). Scientometric Study of the Legislation. Science and science of science, 4(98), 46-64 [in Ukrainian].

14. Nalimov, V. V., Mulchenko, Z. M. (1969). Scientometrics. Studying the development of science as an information process. Moscow: Nauka [in Russian].

15. Haitun, S. D. (1983). Scientometrics: Status and Prospects. Moscow: Nauka [in Russian].

16. Čech, R., Popescu, I.-I., Altmann, G. (2013). Methods of analysis of a thematic concentration of the text. Czech and Slovak Linguistic Review, 3, 4-21.

17. Čech, R., Garabík, R., Altmann, G. (2015). Testing the thematic concentration of text. Journal of Quantitative Linguistics, 22, 215-232. 
18. Tkachuk, A. (2011). Legislative Technique: a Textbook. Kyiv: Legal Status ICC.

19. All Documents of database «Legislation of Ukraine». Awards and honorary titles [classification code 110 ...]. URL: https://zakon.rada.gov.ua/laws/main/en/klas/sp:max100 (Last accessed: 25.02.2019).

20. All Documents of database «Legislation of Ukraine». URL: http://zakon2.rada.gov.ua/laws/main/a\#Find (Last accessed: 25.02.2019).

21. Reshota, V. V. (2017). Acts of Ukraine's President as Sources of Administrative Law. Juridical scientific and electronic journal [Electronic journal], 5, 100-103 [in Ukrainian]. URL: http://zakon2.rada.gov.ua/laws/main/a\#Find (Last accessed: 20.02.2019).

Received 25.04.19

Revised 25.04.19

Accepted 30.05.19

\section{С.Г. Бублик, I.О. Булкін, О.А. Мех}

Державна установа «Інститут досліджень науково-технічного потенціалу

та історії науки ім. Г.М. Доброва НАН України»,

бул. Шевченка, 60, Київ, 01032, Україна,

+380444869591, S.Boublyk@nas.gov.ua

\section{НАУКОМЕТРИЧНЕ ОЦНЮВАННЯ НАУКОВОЇ СПРЯМОВАНОСТІ ВІТЧИЗНЯНОГО ЗАКОНОДАВСТВА}

Вступ. Можливість розбудови наукоємної економіки в Україні залежить від впровадження стратегічних підходів до формування та здійснення єдиної державної науково-технологічної політики. Однією з основних умов впровадження ефективної державної політики є кількісне та якісне наповнення чинного нормативно-правового поля документами наукової спрямованості.

Проблематика. Актуальним науковим завданням постає оцінювання наукової спрямованості актів законодавства як кількісного критерію «наукоємності» вітчизняного законодавства.

Мета. Виконати наукометричне оцінювання наукової спрямованості актів вітчизняного законодавства.

Матеріали й методи. Основними методами дослідження були: наукометричний (сленговий) метод аналізу текстів нормативно-правових актів, а також статистичні методи структурування та порівняльного аналізу актів законодавства як статистичних одиниць.

Результати. Дослідження статистичної бази актів законодавства вищих органів державної влади протягом 19922018 років виявило тенденції взаємної неузгодженості прийняття управлінських рішень вищими органами державної влади. Окрім того, було встановлено періодичні, стійкі статистичні взаємозв'язки між інтенсивністю наукової нормотворчості та рівнями витрат на наукову й науково-технічну діяльність. Розроблено оригінальні наукознавчі підходи до оцінки наукової спрямованості вітчизняного законодавства.

Висновки. До основних проблем державного управління щодо науково-технологічної сфери в Україні протягом Доби Незалежності належали: управлінські конкуренції за виконавчі повноваження в країні між Кабінетом міністрів та Адміністрацією Президента; зосередження уваги Кабміну на функції перерозподілу видатків на науку; відсутність державних стратегічних (тривалих) підходів до формування та здійснення єдиної (наскрізної) державної (публічної) науково-технологічної політики. Необхідним є реформування системи законодавства України в контексті ії наукової спрямованості, зокрема через нагальну необхідність адаптації іï до законодавства Європейського Союзу у сфері науки, технологій та інновацій.

Ключові слова: наука, законодавство, акт законодавства наукової спрямованості, науково-технологічна сфера, індекс наукової спрямованості. 